\title{
BRPKM
}

Buletin Riset Psikologi dan Kesehatan Mental

http://e-journal.unair.ac.id/index.php/BRPKM

e-ISSN: 2776-1851

ARTIKEL PENELITIAN

\section{Makna Pernikahan pada Generasi Milenial yang Menunda Pernikahan dan Memutuskan untuk Tidak Menikah}

\author{
ADILAH NURVIANA \& WIWIN HENDRIANI* \\ Fakultas Psikologi Universitas Airlangga
}

\begin{abstract}
ABSTRAK
Penelitian ini bertujuan menggali makna pernikahan pada generasi milenial yang menunda dan memutuskan tidak menikah. Penelitian merupakan penelitian kualitatif dan menggunakan pendekatan analisis isi. Partisipan berjumlah 60 milenial (lahir tahun 1982-2000), terbagi menjadi dua kelompok yaitu kelompok penunda (63,3\%) dan kelompok penolak (36,7\%). Mereka tersebar di seluruh Indonesia meskipun dominan Jawa Barat dan Jawa Timur. Hasil penelitian adalah: (1) bagi kelompok penunda, pernikahan adalah tahapan hidup baru, hidup bersama pasangan, jangan egois, harus kondusif untuk membesarkan anak, idealnya pasangan adalah orang tercinta, tempat di mana pasangan harus dewasa, ibadah, jangan dilakukan karena tekanan orang lain, butuh persetujuan kedua pihak, harus dilakukan dengan serius, sarana melahirkan generasi baru, dan dilakukan oleh pria dan wanita; (2) bagi kelompok penolak, pernikahan itu rumit, beban, tidak abadi, beresiko, meragukan, harus didasari rasa ketertarikan, bukan milestone, tidak penting, tidak sakral, dan butuh kesabaran.
\end{abstract}

Kata kunci: kualitatif, makna, milenial, pernikahan

\section{ABSTRACT}

Study aims to explore meaning of marriage in millennials who delays and decides to not marry. This research is a qualitative research and uses content analysis approach. Participants are 60 millennials split into two; Postponers (63,3\%) and Rejectors (36,7\%). They live across Indonesia although dominant in West and East Java. Postponers views marriage as a new life stage, living with partner, don't be selfish, must be conducive to raise children, partner is ideally a loved one, a place where couple must act maturely, sacred, don't marry if others pressures you, needs mutual agreement to do, must be taken seriously, place to birth new generations, and carried out by men-and-women, while rejectors views marriage as a burden, complicated, not eternal, risky, doubtful, must be based on a sense of mutual interest, not a milestone, unimportant, not sacred, and requires patience.

Key words: marriage, meaning, millennials, qualitative

Buletin Penelitian Psikologi dan Kesehatan Mental (BRPKM), 2021, Vol. 1(2), 1037-1045

*Alamat korespondensi: Fakultas Psikologi Universitas Airlangga, Kampus B Universitas Airlangga Jalan

Airlangga 4-6 Surabaya 60286. Surel: wiwin.hendriani@psikologi.unair.ac.id 
sehingga penggunaan, distribusi, reproduksi dalam media apapun atas artikel ini tidak dibatasi, selama sumber aslinya disitir dengan baik.

\section{PENDAHULUAN}

Pernikahan dan perkawinan merupakan dua hal yang mirip namun secara pengertian merujuk pada dua aktivitas yang berbeda. Kawin yaitu (1) membentuk keluarga dengan lawan jenis; bersuami atau beristri; menikah; (2) melakukan hubungan kelamin; berkelamin (untuk hewan); (3) bersetubuh; (4) perkawinan (KBBI, 2016). Sementara nikah adalah ikatan (akad) perkawinan yang dilakukan sesuai dengan ketentuan hukum dan ajaran agama (KBBI, 2016). Berdasarkan definisi KBBI di atas, perbedaan antara kawin dan nikah adalah sebagai berikut: perkawinan lebih menekankan para pembentukan keluarga dan melibatkan persetubuhan. Pernikahan merupakan peristiwa yang diidamkan mayoritas di mana seseorang bersatu dengan yang dicintainya. Kehendak untuk melangsungkan pernikahan yang dipandang baik secara normatif tersebut nyatanya tidak selalu dianggap positif.

Generasi milenial, atau kelompok manusia yang lahir mulai tahun 1982 sampai 2000 (Howe \& Strauss, 2000), banyak mengalami ketakutan untuk berkomitmen dalam berumah tangga, sehingga hal ini menyebabkan mereka enggan untuk menikah (Hartanto, 2016). Pernikahan sebagai tahap hidup yang positif nyatanya mulai dikesampingkan dan dinilai berbeda oleh generasi milenial (Wang \& Taylor, 2011). Generasi milenial cenderung menunda pernikahan dan cenderung mengganggap bahwa pernikahan tidak begitu penting untuk disegerakan atau bahkan dilakukan (Wang \& Taylor, 2011). Generasi milenial dikatakan juga memiliki kecenderungan melakukan kohabitasi, cenderung lebih menghargai parenthood daripada pernikahan (Wang \& Taylor, 2011), dan cenderung bersedia membesarkan anak meski tanpa pasangan.

Fenomena serupa juga terjadi di Indonesia. Generasi milenial lebih pemilih dalam menentukan pasangan hidup dan mementingkan stabilitas finansial sebelum memutuskan untuk lanjut ke jenjang pernikahan (Badan Pusat Statistik, 2018). Persentase generasi milenial yang belum menikah menurut Susenas 2017 sejumlah 43,46 persen, berarti persentase generasi milenial yang belom menikah masih tergolong tinggi meskipun lebih dari setengah generasi milenial $(54,45 \%)$ telah berstatus menikah (Badan Pusat Statistik, 2018). Menurut mereka, salah satu penyebab mereka menunda pernikahan adalah karena banyak di antara mereka masih pelajar (Badan Pusat Statistik, 2018). Generasi milenial yang berpendidikan tinggi seringkali menunda pernikahan, bahkan memutuskan untuk tidak menikah (Silalahi, 2018), karena mereka memercayai pendidikan sebagai aspek kedewasaan yang lebih penting dari pernikahan (Calfas, 2017). Fenomena absennya keinginan untuk menikah tentu menjadi masalah, karena hanya pernikahan yang memberikan perlindungan secara hukum sekaligus cara agar sebuah hubungan kehidupan berpasangan dapat diterima dan diakui secara sosial oleh masyarakat.

Cara pandang generasi milenial terhadap pernikahan secara tidak langsung berpengaruh pada keputusan pernikahan mereka (Badan Pusat Statistik, 2018). Cara individu dalam memaknai suatu hal dipercaya sebagai kekuatan vital bagi sikap dan perilaku individu (Özyiğit, 2017). Sejauh ini, masih sedikit peneliti yang mencoba mendalami seperti apa makna pernikahan bagi anak-anak muda (Kefalas dkk., 2011). Melakukan penelitian terhadap makna pernikahan diyakini dapat menjawab mengapa fenomena-fenomena penundaan pernikahan pada generasi milenial yang sudah dipaparkan sebelumnya dapat terjadi, sehingga menjadi catatan menarik untuk dikaji lebih lanjut.

Pertanyaan utama dalam penelitian ini adalah "Bagaimana makna pernikahan bagi generasi milenial yang menunda pernikahan?" dan "Bagaimana makna pernikahan bagi generasi milenial yang

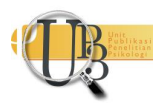


memutuskan untuk tidak menikah?" Tujuan penelitian ini adalah untuk menggali makna pernikahan pada generasi milenial yang menunda pernikahan serta generasi milenial yang memutuskan untuk tidak menikah. Manfaat teoretisnya adalah (1) memberikan pemahaman mengenai makna pernikahan pada generasi milenial yang menunda pernikahan; (2) memberikan pemahaman mengenai makna pernikahan pada generasi milenial yang memutuskan untuk tidak menikah; dan (3) memperkaya hasil penelitian psikologi mengenai makna pernikahan pada generasi milenial, khususnya generasi milenial yang menunda pernikahan dan generasi milenial yang memutuskan untuk tidak menikah. Manfaat praktisnya adalah (1) penelitian ini diharapkan dapat digunakan oleh generasi milenial sebagai bahan pertimbangan atau referensi sebelum memutuskan untuk menikah maupun tidak; (2) generasi milenial diharapkan dapat memutuskan untuk menikah atau tidak atas kesadaran/pertimbangan sendiri; dan (3) memberikan pemahaman kepada beberapa masyarakat awam bahwa generasi milenial memiliki alasan sendiri untuk menunda pernikahan atau memutuskan untuk tidak menikah.

Penelitian ini menggunakan perspektif interaksi simbolik. Interaksi simbolik memiliki tiga premis (Blumer, 1969). Premis pertama adalah bahwa cara seseorang mendefinisikan atau memahami suatu hal dapat memengaruhi perilaku seseorang dalam menyikapi hal yang berkaitan dengan hal tersebut. Premis kedua adalah bahwa makna dari hal-hal tersebut berasal (atau muncul) dari interaksi sosial yang terjadi di antara seseorang dengan sesamanya. Premis ketiga adalah bahwa makna-makna ini ditangani (dan dimodifikasi) melalui proses penafsiran yang digunakan oleh orang tersebut dalam menghadapi hal-hal yang ditemuinya. Berdasarkan ketiga premis ini, nteraksi simbolik memberikan perspektif yang berguna untuk menganalisis bagaimana orang mendefinisikan dan bertindak terhadap hal yang berkaitan dengan pernikahan (Hall, 2006).

\section{METODE}

Tipe penelitian dalam penelitian ini adalah penelitian kualitatif. Pendekatan yang digunakan untuk penelitian ini adalah pendekatan analisis isi. Tujuan dari analisis isi adalah untuk mengatur dan menarik makna dari data yang sudah terkumpul dan mengambil kesimpulan realistis berdasarkan makna tersebut (Bengtsson, 2016). Melalui analisis isi, penulis dapat mengolah segala jenis data tertulis, dari manapun asal bahan tersebut (Bengtsson, 2016), contohnya adalah pertanyaan open-ended dalam sebuah kuesioner (Donath dkk., 2011), sehingga penulis memutuskan untuk menggunakan kuesioner berisi pertanyaan terbuka (atau open-ended question) sebagai teknik penggalian data.

Teknik penentuan partisipan yang digunakan dalam penelitian ini adalah purposive sampling. Tidak ada kriteria tertentu dalam penentuan jumlah partisian yang hendak diteliti (Bengtsson, 2016). Partisipan dalam penelitian ini adalah 60 generasi milenial (lahir tahun 1982-2000) yang terbagi menjadi dua kelompok sesuai dengan keputusan mereka, yaitu menunda (38 partisipan) atau tidak menikah (22 partisipan), tinggal di Indonesia, dan telah membaca informed consent dengan seksama serta bersedia untuk terlibat sebagai partisipan dengan mengisi kuesioner secara lengkap. Kelompok penunda pernikahan terdiri dari 30 partisipan perempuan dan 13 partisipan laki-laki sedangkan kelompok penolak pernikahan terdiri dari 20 partisipan perempuan dan dua partisipan laki-laki. Seluruh partisipan dalam penelitian ini berasal dari berbagai daerah di Indonesia, di antaranya: Jawa Barat (16 orang), Jawa Timur (15 orang), DKI Jakarta (8 orang), Banten (8 orang), Jawa Tengah (3 orang), Daerah Istimewa Yogyakarta (3 orang), Sumatera Selatan (3 orang), Bali (1 orang), Sumatera Utara (1 orang), Riau (1 orang), dan Kalimantan Barat (1 orang). Partisipan dalam penelitian ini berusia 19-31 tahun, dengan partisipan yang berusia 19 tahun sejumlah 3 orang, usia 20 tahun sejumlah 6 orang, usia 21 tahun sejumlah 10 orang, usia 22 tahun sejumlah 7 orang, usia 23 tahun sejumlah 14 orang, usia 24 
tahun sejumlah 9 orang, usia 25 tahun sejumlah 4 orang, usia 26 tahun sejumlah 2 orang, usia 27 hanya satu orang, usai 28 tahun sejumlah 3 orang, dan usia 31 tahun hanya satu orang.

Teknik pengorganisasian dan analisis data yang dilakukan dalam penelitian ini adalah dengan mengidentifikasi unit makna, memasukkan konten relevan dan membuang data yang tidak relevan, identifikasi grup yang serupa, kemudian tarik kesimpulan yang realistis (Bengtsson, 2016).

\section{HASIL PENELITIAN}

Berdasarkan data yang disampaikan oleh para partisipan, terdapat dua kelompok temuan berdasarkan rencana pernikahan, yaitu: (1) Menunda untuk menikah hingga mencapai usia tertentu dan (2) Tidak ingin menikah. Pilihan menunda menandakan bahwa pernikahan masih terpikirkan oleh 30 partisipan yang secara nyata menyatakan akan menunda pernikahan.

Terkait dengan kedua rencana terhadap pernikahan tersebut, alasan-alasan yang muncul tentang pernikahan baik dari partisipan laki-laki maupun perempuan berlandaskan pada permasalahan komitmen pernikahan sendiri. Hampir seluruh partisipan mengatakan bahwa kesakralan dan komitmen pernikahan yang harus dilangsungkan seumur hidup menjadi dasar ketikdaksiapan mereka untuk menjalani pernikahan di usia muda. Alasan finansial dan bayangan perceraian juga dikemukakan oleh kurang dari setengah partisipan perempuan. Walaupun jumlah partisipan laki-laki tidak sebanding dengan partisipan perempuan namun pendapat yang sama juga dikemukakan oleh partisipan laki-laki. Bagi mayoritas partisipan laki-laki pernikahan menunda pernikahan adalah pilihan yang tepat mengingat tanggung jawab yang dibebankan kepada suami nantinya sehingga tidak bisa jika hanya dipertimbangkan berdasarkan keputusan yang singkat.

Alasan dominan untuk membahagiakan orang tua dan melanjutkan pendidikan menunjukkan bahwa kebutuhan ekonomi dan pendidikan menjadi hal yang utama dalam menunda pernikahan. Kemudian terdapat ketimpangan antara ekspektasi partisipan (di mana sebenarnya dia menganggap pernikahan sebagai ibadah suci yang tidak akan merusak diri), dengan kenyataan di sekitarnya (di mana orang lain menyuruh-nyuruh untuk menikah muda padahal ujung-ujungnya bercerai juga).

Pandangan mengenai pernikahan pada partisipan perempuan mayoritas menitikberatkan pada pengalaman yang mereka dapat dari orang-orang terdekat di sekitar mereka. Reponden memberikan contoh-contoh, yang mereka yakini konkrit, bagaimana komitmen pernikahan yang seharusnya menjadi janji seumur hidup juga bisa runtuh pada perceraian. Isu perceraian dan tidak adanya jaminan kebahagiaan setelah melalui proses pernikahan menjadi pandangan yang dominan disuarakan oleh partisipan perempuan. Ketidakpercayaan ini disebabkan oleh faktor lingkungan yang cenderung menganggap pernikahan sebagai sesuatu yang "senang di awal" dan berkaitan dengan legalitas hubungan seks dengan pasangan namun melupakan esensi dari pernikahan sendiri. Bagi partisipan perempuan yang memilih untuk tidak menikah menganggap bahwa pernikahan bukanlah suatu pencapaian atau tujuan hidup yang utama. Alasan-alasan seperti banyaknya tanggung jawab, kerumitan urusan dengan keluarga besar hingga ketidak abadian pernikahan menjadi pandangan bagi partisipan perempuan yang memilih pilihan ini.

Sementara pada partisipan laki-laki, pandangan yang mereka miliki tentang pernikahan tidak jauh berbeda. Pembahasan tentang komitmen seumur hidup dan beban tanggung jawab menjadi alasan utama bagi partisipan laki-laki yang memilih untuk menunda atau tidak menikah. Namun, alasan finansial menjadi isu tambahan bagi partisipan laki-laki. Salah satu contoh beban sebagai kepala rumah 
tangga yang hampir selalu dikaitkan dengan keuangan diungkapkan oleh partisipan laki-laki. Penambahan permasalahan finansial pada partisipan laki-laki tentu berkaitan dengan asumsi sosial yang sangat mendasar bahwa laki-laki adalah kepala rumah tangga yang juga harus menjadi breadwinner atau pemberi nafkah bagi istri dan anaknya. Sehingga kestabilan ekonomi dan pekerjaan yang mapan menjadi penting bagi partisipan laki-laki dalam memutuskan kesiapan untuk menikah.

Hal menarik muncul pada respon terhadap pertanyaan harapan partisipan untuk kehidupan mereka 10 tahun mendatang. Walaupun secara umum partisipan baik wanita maupun laki-laki memilih untuk menunda pernikahan dengan pandangan-pandangan yang telah disebutkan di atas, namun pada datanya, harapan mereka adalah dapat hidup bahagia bersama dengan keluarga, yaitu suami dan anak. Partisipan memiliki harapan untuk sudah menikah di 10 tahun yang akan datang, memiliki keluarga yang bahagia dan berkecukupan. Jika isu finansial pada pandangan pernikahan didominasi oleh partisipan laki-laki, pada harapan pernikahan partisipan wanita pun juga memiliki respon yang sama, yaitu ingin memiliki pekerjaan yang mapan atau keluarga yang tercukupi segala kebutuhannya.

Bagi generasi milenial yang menolak untuk menikah, kemapanan finansial menjadi harapan dominan untuk 10 tahun mendatang. Mayoritas partisipan menyebutkan pemenuhan kebutuhan materi seperti rumah, mobil, dan pekerjaan dengan pemasukan yang stabil menjadi target yang harus mereka capai dalam kehidupan 10 tahun mendatang. Hal ini bisa menjadi sebuah simpulan bahwa pernikahan dan kestabilan finansial menjadi pertimbangan mutlak bagi partisipan milenial yang tidak kalah pentingnya dengan komitmen pernikahan. Dapat juga dikatakan bahwa finansial merupakan bagian dari komitmen pernikahan yang harus dicapai dalam rangka mewujudkan pernikahan yang bahagia berdasarkan definisi partisipan dari generasi milenial.

\section{DISKUSI}

Penelitian "Makna Pernikahan pada Generasi Milenial (Studi pada Generasi Milenial yang Menunda Pernikahan dan Memutuskan Tidak Menikah)" melibatkan 60 partisipan generasi milenial, di mana 38 partisipan menunda pernikahan sementara 22 sisanya memutuskan untuk tidak menikah. Sebelum melakukan pembahasan terhadap hasil penelitian, penulis akan membahas tiga premis interaksi simbolik oleh (Blumer, 1969) terlebih dahulu. Premis pertama adalah bahwa cara seseorang mendefinisikan atau memahami suatu hal dapat memengaruhi perilaku seseorang dalam menyikapi hal yang berkaitan dengan hal tersebut (Blumer, 1969). Premis kedua adalah bahwa makna dari hal-hal tersebut berasal (atau muncul) dari interaksi sosial yang terjadi di antara seseorang dengan sesamanya (Blumer, 1969). Terakhir, premis ketiga adalah bahwa makna-makna ini ditangani (dan dimodifikasi) melalui proses penafsiran yang digunakan oleh orang tersebut dalam menghadapi hal-hal yang ditemuinya (Blumer, 1969).

Pada kelompok generasi milenial yang menunda pernikahan, mereka memahami bahwa pernikahan itu (1) sesuatu yang hanya boleh dilakukan jika sudah siap secara fisik, mental, dan finansial dan sudah dipikirkan secara matang- matang; (2) sakral; (3) tahapan hidup baru; (4) idealnya dilakukan sekali untuk selamanya; (5) perlu banyak komitmen dan tanggung jawab; (6) menjalani hidup bersama pasangan; (7) partnership; (8) keadaan terikat dengan pasangan; (9) mempersatukan dua manusia; (10) jangan berat sebelah; (11) harus dibangun agar kondusif untuk anak (harus bisa parenting) (12) pilihan/opsional; (13) tempat di mana pasangan harus bersikap dewasa; (14) konformitas atau dilakukan agar diterima oleh masyarakat; (15) ibadah; (16) sarana untuk membangun keluarga atau melahirkan generasi baru; (17) jangan dilakukan karena suruhan, tekanan, paksaan, atau gunjingan orang lain; (18) jangan dilakukan hanya karena nafsu; (19) butuh persetujuan kedua-belah pihak, (20) 
tidak mudah; (21) harus dilakukan dengan serius; dan (22) dilakukan oleh pria dan wanita. Jika mengacu pada premis pertama dari perspektif interaksi simbolik (Blumer, 1969), dapat dikatakan bahwa pandangan-pandangan tentang pernikahan yang dimiliki oleh kelompok generasi milenial inilah yang menyebabkan munculnya perilaku menunda pernikahan.

Beberapa partisipan dari kelompok milenial penunda pernikahan beserta pengalaman dan interaksi dengan sekitar mereka sangat sesuai dengan premis kedua dari perspektif interaksi simbolik (Blumer, 1969) bahwa makna dari hal-hal tersebut berasal (atau muncul) dari interaksi sosial yang terjadi di antara seseorang dengan sesamanya.

Pada kelompok generasi milenial yang memutuskan untuk tidak menikah, mereka memahami bahwa pernikahan itu (1) harus siap (baik secara finansial maupun mental dan harus siap untuk hidup bersama pasangannya seumur hidup) dan harus dipikirkan matang-matang sebelum menikah maupun punya anak; (2) butuh komitmen besar dan banyak tanggung jawab; (3) partnership, (4) rumit/ruwet/kompleks; (5) berat/beban; (6) tidak abadi, (7) beresiko/dapat menimbulkan berbagai permasalahan; (8) opsional/bukan kewajiban; (9) jangan didasarkan atas suka-sama-suka, (10) meragukan; (11) persatuan/ikatan; (12) sakral, (13) bukan milestone/tujuan hidup; (14) tidak penting, (15) harus bahagia dan didasari rasa ketertarikan; (16) bukan hal sakral lagi; dan (17) tekanan sosial. Jika mengacu pada premis pertama dari perspektif interaksi simbolik (Blumer, 1969), dapat dikatakan bahwa pandangan-pandangan tentang pernikahan yang dimiliki oleh kelompok generasi milenial inilah yang menyebabkan munculnya perilaku menolak pernikahan.

Sama halnya dengan kelompok generasi milenial yang menunda pernikahan, kelompok generasi milenial yang memutuskan untuk tidak menikah ini juga memeroleh pemahaman seperti disebutkan di atas melalui orang-orang di sekitarnya. Contoh partisipan ini beserta pengalaman mereka dalam menghadapi sekitarnya sangat sesuai dijelaskan menggunakan premis kedua dari perspektif interaksi simbolik yang menyatakan bahwa makna dari hal-hal tersebut berasal (atau muncul) dari interaksi sosial yang terjadi di antara seseorang dengan sesamanya (Blumer, 1969).

Premis terakhir atau premis ketiga dari perspektif interaksi simbolis adalah bahwa makna-makna ini ditangani (dan dimodifikasi, dan diperbarui, dan disempurnakan) melalui proses penafsiran yang digunakan oleh orang tersebut dalam menghadapi hal-hal yang ditemuinya (Blumer, 1969). Berdasarkan premis tersebut, maka makna dapat berubah sesuai dengan konteks dalam ruang dan waktu yang membingkai interaksi (Laksmi, 2018). Partisipan dari kedua kelompok di atas sama-sama mengamati dan berinteraksi dengan sekitarnya, tetapi cara mereka dalam menafsirkan makna itu berbeda sehingga menghasilkan perilaku yang berbeda (menunda pernikahan atau memutuskan untuk tidak menikah). Hal ini dapat dijelaskan menggunakan teori psikologi kognitif karena penafsiran adalah penggunaan pengetahuan kognitif, untuk menganalisis, mensintesis, memahami, dan mengungkapkan informasi yang masuk (Guo, 2016), sehingga penafsiran termasuk proses kognitif.

Untuk membantu menjelaskan premis ketiga ini, penulis akan menjelaskan sedikit tentang psikologi kognitif. Psikologi kognitif adalah ilmu yang memelajari bagaimana seseorang mempersepsikan, belajar, mengingat, dan berpikir mengenai suatu informasi. Psikologi kognitif berkutat dengan cara individu memeroleh dan memroses informasi mengenai dunia, cara informasi tersebut disimpan dan diproses oleh otak, cara individu menyelesaikan masalah, berpikir dan menyusun bahasa, dan bagaimana prosesproses ini ditampilkan dalam perilaku yang dapat diamati (Solso dkk., 2014). Terdapat 12 ruang lingkup dalam psikologi kognitif. Salah satu dari ke-12 ruang lingkup tersebut adalah proses berpikir dan pembentukan konsep (Solso dkk., 2014). Pemaknaan termasuk dalam ruang lingkup tersebut. Ruang lingkup ini mencakup berpikir, pembentukan konsep, dan pengambilan keputusan. 
Berpikir adalah proses internal yang membentuk representasi mental baru melalui transformasi informasi oleh interaksi kompleks dari atribusi mental yang mencakup pertimbangan, pengabstrakan, penalaran, penggambaran, pemecahan masalah logis, pembentukan konsep, kreativitas, dan kecerdasan (Solso dkk., 2014). Cakupan kedua adalah pembentukan konsep. Salah satu bentuk representasi mental baru yang dapat dihasilkan melalui proses berpikir adalah konsep. Konsep adalah ide maupun sekumpulan ide (baik nyata maupun abstrak) yang merepresentasikan kategori-kategori informasi atau unit-unit pengetahuan (Solso dkk., 2014). Sementara itu, pembentukan konsep adalah penegasan terhadap sifat-sifat yang biasa ditemui dalam suatu kelas objek ataupun ide (Solso dkk., 2014). Cakupan ketiga dari ruang lingkup pemaknaan adalah pengambilan keputusan. Terdapat tiga teknik penalaran, salah satunya adalah inductive reasoning. Inductive reasoning (penalaran induktif) adalah teknik penalaran di mana suatu kesimpulan ditarik dari prinsip yang lebih khusus ke prinsip yang lebih umum (Solso dkk., 2014). Penalaran induktif menghasilkan kesimpulan yang seringkali dinyatakan secara implisit maupun eksplisit dalam konteks pernyataan probabilitas (Solso dkk., 2014).

Berdasarkan deskripsi temuan yang sudah dipaparkan, diketahui adanya tiga pokok temuan dalam penelitian ini, yaitu pandangan terhadap pernikahan, harapan terhadap 10 tahun mendatang, dan alasan memilih menunda atau tidak menikah. Apabila ketiga temuan tersebut dicocokkan dengan ketiga cakupan proses berpikir dan pembentukan konsep di atas, dapat dikatakan bahwa makna ditafsir melalui 3 tahapan proses kognitif, yaitu berpikir (berisi padangan terhadap pernikahan), pembentukan konsep (harapan yang dibangun), dan pengambilan keputusan (beserta alasan mengapa partisipan memutuskan menunda atau tidak menikah). Sehingga cara partisipan dalam memroses makna tersebut hingga mereka dapat mengambil kesimpulan dapat digambarkan sebagai berikut.

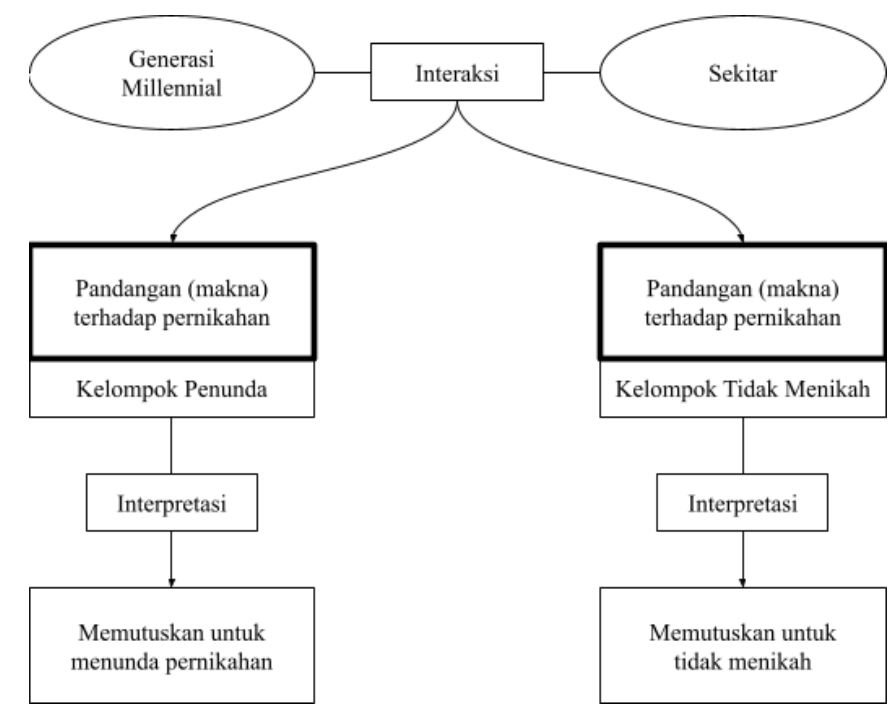

Gambar 1. Bagan makna pernikahan pada generasi milenial yang memutuskan untuk menunda pernikahan dan generasi milenial yang memutuskan untuk tidak menikah. 


\section{SIMPULAN}

Berdasarkan hasil analisis data dan pembahasan yang telah dituliskan pada bab sebelumnya, kesimpulan dari penelitian ini adalah kelompok generasi milenial yang memutuskan menunda pernikahan memaknai bahwa pernikahan itu (1) sesuatu yang hanya boleh dilakukan jika sudah siap secara fisik, mental, dan finansial dan sudah dipikirkan secara matang-matang; (2) sakral; (3) tahapan hidup baru; (4) idealnya dilakukan sekali untuk selamanya; (5) perlu banyak komitmen dan tanggung jawab; (6) menjalani hidup bersama pasangan; (7) partnership; (8) keadaan terikat dengan pasangan; (9) mempersatukan dua manusia; (10) jangan berat sebelah; (11) harus dibangun agar kondusif untuk anak (harus bisa parenting) (12) pilihan/opsional; (13) tempat di mana pasangan harus bersikap dewasa; (14) konformitas atau dilakukan agar diterima oleh masyarakat; (15) ibadah; (16) sarana untuk membangun keluarga atau melahirkan generasi baru; (17) jangan dilakukan karena suruhan, tekanan, paksaan, atau gunjingan orang lain; (18) jangan dilakukan hanya karena nafsu; (19) butuh persetujuan kedua-belah pihak; (20) tidak mudah; (21) harus dilakukan dengan serius; dan (22) dilakukan oleh pria dan wanita. Makna-makna ini menyebabkan mereka menunda pernikahan.

Selain itu, kelompok generasi milenial yang memutuskan untuk tidak menikah memaknai bahwa pernikahan itu (1) harus siap (baik secara finansial maupun mental dan harus siap untuk hidup bersama pasangannya seumur hidup) dan harus dipikirkan matang-matang sebelum menikah maupun punya anak; (2) butuh komitmen besar dan banyak tanggung jawab; (3) partnership; (4) rumit/ruwet/kompleks; (5) berat/beban; (6) tidak abadi; (7) beresiko/dapat menimbulkan berbagai permasalahan; (8) opsional/bukan kewajiban; (9) jangan didasarkan atas suka-sama-suka; (10) meragukan; (11) persatuan/ikatan; (12) sacral; (13) bukan milestone/tujuan hidup, (14) tidak penting; (15) harus bahagia dan didasari rasa ketertarikan; (16) bukan hal sakral lagi; dan (17) tekanan sosial. Makna-makna ini menyebabkan mereka memutuskan untuk tidak menikah.

Baik pada kelompok generasi milenial yang menunda pernikahan maupun kelompok generasi milenial yang memutuskan untuk tidak menikah, mereka memaknai pernikahan seperti itu berkat interaksi dengan sekitar mereka, Saat berinteraksi dengan sekitar, mereka mengolah makna tersebut melalui proses interpretasi. Proses interpretasi ini mengarahkan mereka untuk mengambil keputusan, yaitu untuk menunda pernikahan atau tidak menikah.

\section{DEKLARASI POTENSI TERJADINYA KONFLIK KEPENTINGAN}

Adilah Nurviana dan Wiwin Hendriani tidak bekerja, menjadi konsultan, memiliki saham, atau menerima dana dari perusahaan atau organisasi manapun yang mungkin akan mengambil untung dari diterbitkannya naskah ini.

\section{PUSTAKA ACUAN}

Badan Pusat Statistik. (2018). Statistik Gender Tematik: Profil Generasi Milenial Indonesia. Kementrian Pemberdayaan Perempuan dan Perlindungan Anak.

Bengtsson, M. (2016). How to Plan and Perform A Qualitative Study using Content Analysis. NursingPlus Open, 2, 8-14. 
Blumer, H. (1969). Symbolic interactionism: Perspective and method. Englewood Cliffs, New Jersey, USA: Prentice Hall.

Calfas, J. (2017, April 10). Millennials Want Jobs and Education, Not Marriage and Kids. Retrieved October 2, 2017, from TIME: https://time.com/4748357/milennials-values-census-report/

Donath, C., Winkler, A., Graessel, E., \& Luttenberger, K. (2011). Day care for dementia patients from a family caregiver's point of view: a questionnaire study on expected quality and predictors of utilisation - Part II. BMC Health Services Research(11), 1-7.

Guo, Y. (2016). Cognitive Analysis of Long-Term Memory in Interpreting. International Journal of Language and Linguistics, 4(3), 103-133.

Hall, S. S. (2006). Marital meaning: exploring young adults' belief systems about marriage. Journal of Family Issues, 27(10), 1437-1458.

Hartanto. (2016, September 4). Mereka yang Takut Menikah. Retrieved October 16, 2020, from Tirto.id: https://tirto.id/mereka-yang-takut-menikah-bGz6

Howe, N., \& Strauss, W. (2000). Milenials Rising: The Next Great Generation. New York City, USA: Vintage Books.

KBBI. (2016). Kawin. Retrieved from KBBI Daring: https://kbbi.kemdikbud.go.id/entri/kawin

KBBI. (2016). Nikah. Retrieved from KBBI Daring: https://kbbi.kemdikbud.go.id/entri/nikah

Kefalas, M. J., Furstenberg, F. F., Carr, P. J., \& Napolitano, L. (2011). "Marriage Is More Than Being Together": The Meaning of Marriage for Young Adults. Journal of Family Issues, 32(7), 845-875.

Laksmi, L. (2007). Teori Interaksionisme Simbolik dalam Kajian Ilmu Perpustakaan dan Informasi. PUSTABIBLIA: Journal of Library, 1(2), 121-138.

Özyiğit, M. K. (2017). The Meaning of Marriage According to University Students: A Phenomenological Study. Educational Sciences: Theory \& Practice, 17(2), 679-711.

Silalahi, J. N. (2018). TANTANGAN HIDUP PEREMPUAN GENERASI MILLENNIAL "BERKARIR ATAU MENIKAH". Jurnal Sosiologi, 1(2), 92-100.

Solso, R. L., Maclin, O. H., \& Maclin, M. K. (2014). Cognitive Psychology. England.

Wang, W., \& Taylor, P. (2011, March 9). For Millennials, Parenthood Trumps Marriage. Retrieved January 17, 2019, from Pew Research Center: https://www.pewresearch.org/socialtrends/2011/03/09/for-millennials-parenthood-trumps-marriage/ 